\title{
Intermodal Transport Strategy for Logistics Center on the Example of "Euroterminal Sławków"
}

\author{
Katarzyna Świerszcz and Bogdan Ćwik \\ Military University of Technology in Warsaw, Warsaw, Poland \\ Correspondence should be addressed to: Świerszcz Katarzyna; katarzyna.swierszcz@wat.edu.pl \\ Received date: 4 September 2017; Accepted date: 26 November 2017; Published date: 2 April 2018 \\ Academic Editor: František Milichovský \\ Copyright (C 2018. Katarzyna Świerszcz and Bogdan Ćwik. Distributed under Creative Commons CC-BY \\ 4.0

\begin{abstract}
The studies attempted to discuss one of the most important and contemporary issues, i.e. the operation of a logistics center on both national and global level in respect of intermodal services, with particular emphasis on transport strategy. The paper is aimed to examine the strategy of rational coordination of flows that can enable connection and organization logistic flows between Asia Region and UE. It started to be realized in Euroterminal Sławków that is localized in south part of Poland and it is an initial part of a wider conception of Transnational Logistics Center on the Polish and Czech border. The issue was described on the basis of the following aspects: 1 . The essence of logistics center operation as a link in a chain of logistics services. 2. Role and significance of intermodal transport for services rendered by a logistics center. 3. "Euroterminal Sławków" as an example of intermodal transport logistics center. The paper is a result of examining the various dates from different business and administrative sources. Many documents and reports were investigated and some results are presented. Analytic and synthetic method was adopted to provide the issues in details. As a result of the work carried out, it is stated that Euroterminal Sławków can fulfill the role of an integrator of flows; integrating and coordinating logistic flows from Asia to the EU and from northern Europe to southern Europe. The paper concludes that future contributions to the topic of Transnational Logistics Center are essential and possible.
\end{abstract}

Keywords: logistics center, logistics services, intermodal transport, quality, added value.

Cite this Article as: Katarzyna Świerszcz and Bogdan Ćwik (2018)," Intermodal Transport Strategy for Logistics Center on the Example of "Euroterminal Sławków"", IBIMA Business Review, Vol. 2018 (2018), Article ID 554344, DOI: $10.5171 / 2018.554344$ 


\section{Introduction}

The role of transport for operation of logistics centers - and even for the entire economy - on both national and global level is continuously increasing. There are several relevant factors driving this increase. One of them is the contribution of transport in creating added values for services rendered and their associated products (goods) by making time and space efficient as a result of physical movement of goods to specified locations on specified time. An equally or even the most important factor is the dependence of companies and shops on transport providing them with procurement and distribution services. This dependence comes from the fact that numerous companies are located in different sites than their sources of supply and recipients of their products. Thus, the importance of intermodal transport services increases in connection with the following phenomena: work specialization and division, mass consumption, product volume economy, constant attempts to reduce costs, development of cooperation, market competition, making product life cycle shorter and pursuing to improve customer service. These issues are additionally overlapped with market globalization widening the gap between senders and recipients. They are often located thousands of kilometers from each other. As supply chains in modern economy expand, the importance of transport ensuring communication between senders and recipients (sellers and buyers) rises. The main aim of the article is to look for solutions to improve the national logistics system in terms of global trends in logistics development. The essential information and observation results were obtained by the method of participatory action research.

\section{The Essence of Logistics Center Operation as a Link in a Chain of Logistics Services}

A logistics center operating as a multi-entity company constituting a substantial link for the provision of logistics services performs several critical functions. According to studies, the highest priority is assigned for: ensuring high customer service quality; optimization of stock; minimization of material and product flow time; coordination, integration and cooperation with various entities on actions related to resource flow as well as decreasing logistics costs to an optimum level (Kalinzi 2016). Let's shortly discuss each of these values constituting the essence of logistics center operation.

The first value is related to ensuring high customer service quality. As numerous studies demonstrate, customer service has recently been the primary stimulus common focusing attention. The terms "customer logistics" and „customer approach”, understood as efficient recipes for success in business, prove that the results of the studies are correct. Therefore, one of the essential matters pertaining to the operation of a logistics center is to have a logistics system for effective customer service, referred to as Efficient Consumer Response (ECR). Logistic components of customer service are features to which customers generally attach special importance. They include: delivery time, product stock availability and flexibility, frequency, promptness, accuracy, completeness and reliability of supplies (Agami, Saleh and Rasmy 2012). One of the main purposes of logistics center operation is referred as „8R": Right product, Right quantity, Right condition/quality, Right place, Right time, Right information, Right price and Right customer.

It should be noted that rates assigned by customers to individual values during order performance are subject to change and depend on market segment, type of products supplied, physical distribution system (traditional, supply chain) and competition growth. The aforemenetioned aspects are quantifiable and measurable. It is also easy to determine their performance standards, that is service standards providing specific 
customer expectations or demands on a given market in relation to logistics services (Kisperska-Moroń and Krzyżaniak 2009:77; Ying Wei 2016).

The second value constituting the essence of logistics center operation is optimization of stock. It is associated with JIT (Just-In-Time) concept for both supply system and stock. JIT suggests that stock should be available as required - not earlier and not later. JIT includes four basic assumptions: no stock; short order performance cycles; frequent replenishment of goods; and high quality (no defects). The concept is used for the management of distribution, stock and schedules, and it consists in delivering strictly defined quantities of materials on required time, allowing to minimize stockrelated costs and waste. In the full sense, it can be said that JIT means not only stock management, but also comprehensive quality culture and partnership with suppliers and employees (Coyle, Bardi and Langley 2010:277).

The third crucial value pertaining to logistics center operation is minimization of material and product flow time. Within the center's logistics operations, this purpose is connected with CRP (Continuous Replenishment) system. It is used for the development of methods of order and supply performance that both eliminate the possibility of stock unavailability and reduce stock on logistics channel or supply chain level. To attain these goals, it is required to retrieve updated data from Points of Sale (POS) which are indispensable for developing stock demand forecasts, placing supplementary orders and controlling product streams - from suppliers, through warehouses to retail shops. The stock replenishment system synchronizes product supply with product demand reported by consumers and end users (Fajczak-Kowalska 2013:121; Bömer and Tadeu 2014). It should be emphasized that CRP is directly correlated with QR (Quick Response) strategy. It is derived from the need to shorten order performance cycle time and restrict its randomness, to complete order in place and on time required by customer or end user, to improve manageability and information control capability in relation to both company and partners participating in the supply chain, as well as to reduce stock with simultaneous increase of responsiveness towards customer needs within the entire supply chain (Coyle, Bardi and Langley 2010:276).

The fourth fundamental value for the essence of logistics center operation includes coordination, integration and cooperation with various entities on actions related to resource flow within supply chain process. It is expressed as the ability to cooperate with other entities and undertake team works to harmonize various actions executed by particular entities (contractors) for achieving common goals superior to individual goals (Kisperska-Moroń and Krzyżaniak 2009:307; Bömer and Tadeu 2014). In other words, this value consists in the capability and need to start joint investments and organizational undertakings used for attaining various individual goals and for yielding to common goals aimed at creating values and gaining competitive advantage. Moreover, coordination, integration and cooperation are to be used to improve the ability to take on common risks and to solve problems jointly (Witkowski 2010:41-42).

The fifth value on which the substance of logistics center operation is based is to reduce logistics costs to an optimum level. Significant reduction of logistics costs to the best - optimum - level is possible owing to efficient management and coordination of individual supply chain internal processes controlled by logistics centers. This, in turn, translates into creating additional values (profits) for all entities constituting a given center (Skowronek and Sariusz-Wolski 2012:263). It is worth noticing that the essence of logistics center operation requires an economic and social perspective, revealing further equally important goals, such as: improved management of operating supply chains; increased intermodality of 
freight transport; best possible use of national and international roads; supporting the development of business on local and national levels by providing logistics services for specific entities from manufacturing, commercial and service industries; proper management of business and greater development of spatial order; local growth; recovery of downtown areas previously used for industrial purposes; and development of logistics services related to municipal logistics. It should be observed that these goals pertaining to the essence of logistics center operation are examined in view of general organization objectives. Thus, the hierarchy of logistics goals must be adapted to company goals and strategy. This mutual relationship between company and logistics goals in respect of strategic and operational actions indicates compatibility of goals of business entities, assuring efficient administration of information resource flow while ensuring appropriate service level (Kisperska-Moroń and Krzyżaniak 2009:295).

\section{Role and Significance of Intermodal Transport for Services Rendered By a Logistics Center}

Intermodal transport is specific for the infrastructure related to logistics center services. In respect of logistics, transport as a business is responsible for haulage (flow) of goods and products from factories, raw material and material suppliers and manufacturers of semi-finished and finished products through wholesalers, agents and warehouses to retail points of sale (shops, market chains) and end consumers. In other words, transport is an essential link (function) connecting other components of logistics supply chain for which a logistics center is responsible (Zamkowska and Zagożdżon 2015:223). It should be noted that aside from its independent function, transport considerably affects or even conditions the performance of other logistics functions of a center, such as: procurement, distribution, product return service, stockbuilding or customer service. Furthermore, transport interacts with other logistics areas and its organization is strictly linked to and affects their operation. Typical examples are relations between transport and warehouse operations, including stock control or logistics-related customer service. If a decision is made on, for instance, reducing delivery speed by utilizing slower means of transport and by limiting haulage frequency, transport costs are decreased. Such actions require the increase of stock level and, as a consequence, the increase of warehouse storage area and of costs related to frozen capital. As far as logistics-related customer service is concerned, it is vital to provide customers with as high product availability as possible by expanding chain of warehouses or executing frequent haulage operations over long distances. Customer service can be improved by the selection of fast yet more expensive means. They ensure shorter delivery time but with higher costs (Majchrzak-Lepczyk and Gołembska 2015:78). It should be pointed out that transport costs are the most important component of the entire structure of logistics costs. They are superior to costs of any other logistics actions, such as stock maintenance, warehousing, order processing, etc.

Changes implemented into global logistics and consistent pursuit to integration of supply chains greatly influence the role and tasks of individual types of transport. Manufacturing concentration, that is organization of production in given single locations (regions) characterized by low production costs, causes that the increasing number of raw materials, materials, semifinished products and finished products is transported on a global level over long distances. Therefore, the importance and utilization of long-distance transport increase. This particularly includes maritime transport that, on a global scale, guarantees the highest cost efficiency of logistics processes (Kowalska-Napora 2015:74). On the other hand, local logistics systems mainly distribution and final delivery systems - are usually based on road transport. In relation to increasing customer 
requirements and higher market standards related to logistics customer service, average delivery distance is consistently decreasing. In comparison with other types of transport, road transport has significant competitive advantage. It is ensured by: easy access to any location; great service operability arising from vehicle fleet availability; high flexibility in adopting to customer needs; relatively fast delivery speed (especially in medium- and short-distance transport); service reliability and promptness of service performance (Grenda, Ślachcińska, Majdan 2017: 165169).

Thanks to these features, road transport is the most popular and expansive means of transport both in Poland and in other EU countries. Demand for the remaining means of transport in Poland slightly differs from this demand in other member states (see Diagram 1).

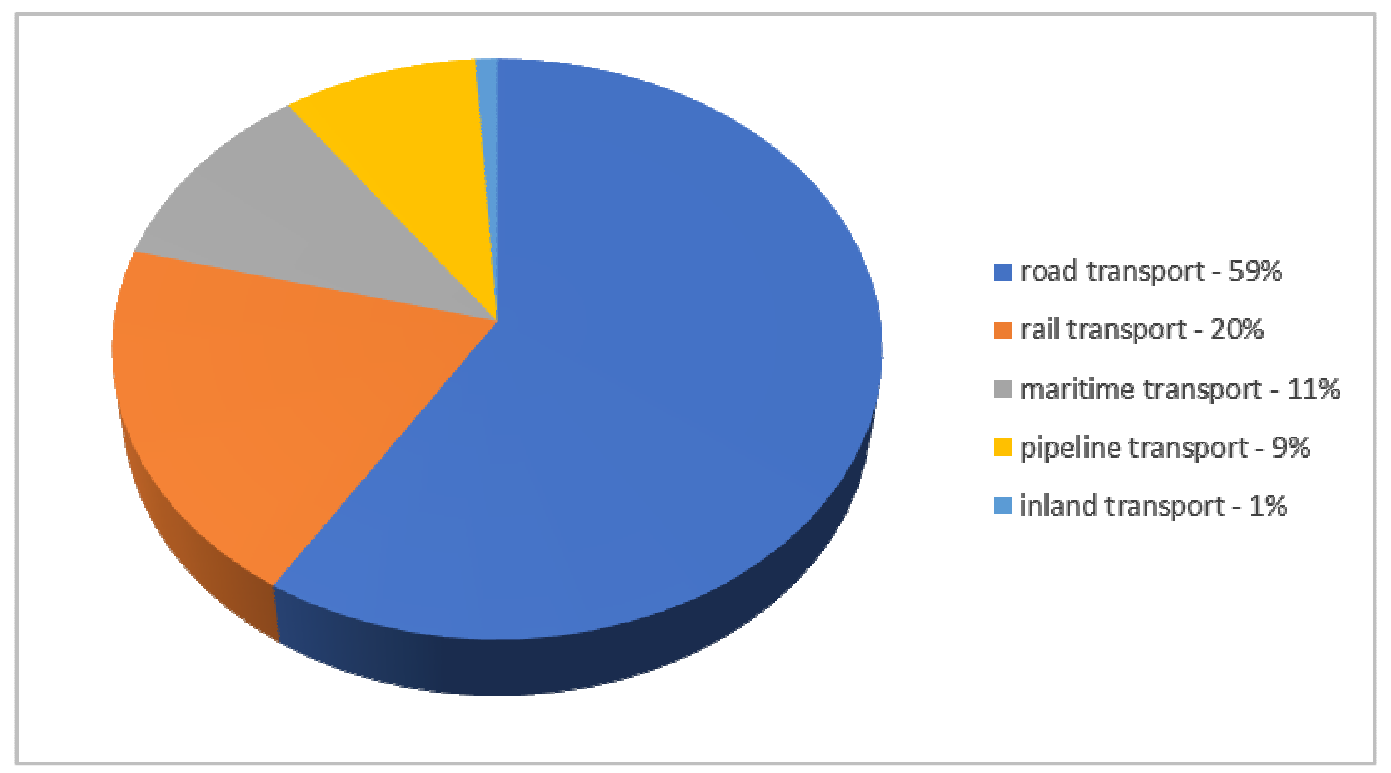

(Source: Own work)

Diagram 1: Types of cargo transport in Poland and in EU countries

The analysis of types of cargo transport used in Poland clearly indicates that the most popular is road transport (59\%) and the following are, respectively, rail transport (20\%), maritime transport (11\%), pipeline transport (9\%) and inland transport (1\%). The same analysis pertaining to EU countries provides slightly other results. The most popular is also road transport (44\%), whereas the following means are, respectively, maritime transport (40\%), rail transport $(10 \%)$, pipeline transport $(3 \%)$ and inland transport (3\%).
Due to this significant discrepancy, the European Union's policy attempts to balance the share of individual means of transport and better utilize the capacity of other means. Furthermore, the European Union in fashion of the United States policy according to which $40 \%$ of cargo is transported by rail - strives to leverage the position of rail transport due to its considerably lower power consumption and reduced environmental pollution (Liberadzki and Mindur 2007:119). 
Deciding on a particular means of transport, a logistics center is always guided by costbenefit (trade-off) analysis and seeks appropriate relations between costs incurred and logistics-related customer service level obtained. In respect of long-term logistics center operation, the latter criterium seems to be more important. In this case (service cost-quality ratio), delivery speed, service reliability, delivery promptness and cargo safety should be considered (KisperskaMoroń and Krzyżaniak 2009:148). Transport plays critical role in the operation of a logistics center responsible for quality and effectiveness of logistics actions (i.e. added value within supply chain). Moreover, special importance is now attached to intermodal transport. The significance of intermodal transport results from distinct work specialization and division, mass consumption, increasing relevance of product volume economy, constant attempts to reduce costs, development of cooperation, severe competition, making product life cycle shorter and pursuing to professional customer service. Market globalization affecting the increase of distances between manufacturers and recipients is also crucial. More and more European companies currently buy goods and materials on Asian or African market and then send their products e.g. to the United States. In the context of modern economy, the longer the supply chain, the greater the importance of intermodal transport that ensures fast, safe, effective and economic connection between senders and recipients, i.e. sellers and buyers. It occurs because the concept of intermodal transport services primarily includes the possibility of using at least two means of transport. For instance: from point A to point $B$ - road transport, from $B$ to $\mathrm{C}-$ rail transport, from $C$ to $D$ - maritime transport, whereas from $\mathrm{D}$ to $\mathrm{E}$ - again road transport. This concept is a systemic approach to transport, covering all transportrelated processes as a coherent, comprehensive and integrated entirety. It should be pointed out that the application of intermodal transport basics requires logistics centers to manage transport processes along the entire route, from sender to recipient, taking into account various economical, technical, engineering, organizational and legal aspects. Such modern transport approach allows more efficient execution of commercial transactions, more effective cooperation of senders and recipients (companies and shops), better customer service quality and at the same time better company quality and reputation as well as its higher profitability (Rydzykowski 2011:217).

\section{"Euroterminal Sławków" Sp. Z 0.0. As An Example of Intermodal Transport Logistics Center}

"Euroterminal Sławków" International Logistics Center is a logistics center located at westernmost point of contact of two types of railway tracks: standard-gauge tracks (with standard European rail width: 1435 $\mathrm{mm}$ ) and broad-gauge tracks $(1524 \mathrm{~mm}$ or $1520 \mathrm{~mm}$ track gauge), being the junction of two Pan-European Transport Corridors connecting the East with the West and the North with the South. Another chief asset of this site is the vicinity of the most urbanized Silesian agglomeration with high demand for transport services.

The aim of Euroterminal construction was to create not only an important center of logistics services provided on transcontinental routes of movement of goods (via Trans-Siberian Railway and the so-called New Silk Road: China - Kazakhstan - Russia - Ukraine - Poland - Western Europe) or a center enabling the combination of maritime and land transport (via ports at the Black Sea and the Adriatic Sea), but also to create positive environment for projects executed on lands belonging to $\mathrm{CZH}$ in Sławków. „Euroteminal Sławków” Logistics Center is currently a state-of-the-art Polish logistics center for intermodal transport that will pursue to increase its competitive capabilities owing to synergy effect (Euroterminal Sławków Sp. z o.o. 2015).

Thanks to its location at the junction of two railway systems, the logistics center in question can provide transshipment of the 
majority of goods. It is a functional and spacious structure with proper infrastructure and organization in which intermodal logistics service related to stock management are rendered. They include: goods receipt, storage, distribution, release and haulage (including non-standard and oversize goods), as well as consolidation and commissioning of goods on pallets, packaging for retail and crossdocking. Additionally, Euroterminal provides transshipment, protections, rail and road forwarding and customs clearance owing to Customs Office that was moved to Sławków. Moreover, the center provides auxiliary services, that is: container unloading (filling and emptying), technical assessment and assessment of suitability for food products, minor container repairs, shipping depot and full terminal service. Logistics advisory and other services are also provided on the basis of customer requirements and expectations. They are rendered by business entities which are independent in relation to senders or recipients (service providers specializing in various logistics issues) (Ibidem).

The aforementioned intermodal services can be provided using "Euroterminal's" container terminal with surface area of $18,550 \mathrm{~m}^{2}$, container overhead crane with lifting capacity $\mathrm{Q}=45 \mathrm{~T}$ and secondary equipment (reach stakers). Total container transshipment capacity exceeds 230,000 TEU per year. Furthermore, the center is equipped with up-to-date warehouses with surface area of $2660 \mathrm{~m}^{2}$ and $4860 \mathrm{~m}^{2}$ and a roofed storage yard with surface area of $3600 \mathrm{~m}^{2}$ with two overhead cranes (lifting capacity of one crane $Q=25 \mathrm{~T}$ ). Both warehouses have access to standard- and broad-gauge tracks.

As can be seen, current capacity of "Euroterminal Sławków" as a state-of-the-art logistics center with extended infrastructure, great transshipment range and the possibility of cargo series handling in virtually all directions, allows to establish a business entity with remarkable potential that can really face up with strong and constantly growing competitors on the logistics market. This is particularly important in view of the scheduled extension of broad-gauge track to Vienna except Poland (international agreements have been signed by stakeholders from Russia, Ukraine, Slovakia and Austria).

Euroterminal construction was executed as a project co-financed by the European Union from European Regional Development Fund as part of „Transport” Operational Programme for years 2004-2006. Investment works consisted in the transformation of the transshipment terminal for conventional goods into a stateof-the-art logistics center for intermodal transport, i.e. utilizing more than one means of transport (rail, road and maritime). Total value of all investments within Euroterminal area completed in recent years using both external sources of financing and CZH own funds exceed PLN 100,000,000.00.

"Euroterminal Sławków" center handles intermodal transport from the Western and Eastern Europe (Ukraine, Russia) and from Polish seaports. Goods in containers are shipped to the east - not only to Moscow or Kiev, but also to South Korea, Afghanistan, Kazakhstan and numerous other markets. Euroterminal also handles railway transport for shipping distributed containers (e.g. to Karaganda, Almaty and Kulsary). Such connections guarantee efficient movement of goods between EU countries, supplied to EU countries by sea, and transport of these goods to Ukraine, Russia, Kazakhstan, Tajikistan and Uzbekistan. It should also be noted that main business partners of "Euroterminal Sławków" logistics center are: PCC Intermodal S.A., Hupac Intermodal (Switzerland) Russkaya Troyka (Russia) and „Liski” Ukrainian National Logistics Center (Ibidem).

As for containerized cargoes, in 2015-2016, cargoes were mainly handled along N-S (north-south) line. Increasing number of containers handled along E-W (east-west) line can also be noticed. See Diagram 2. 


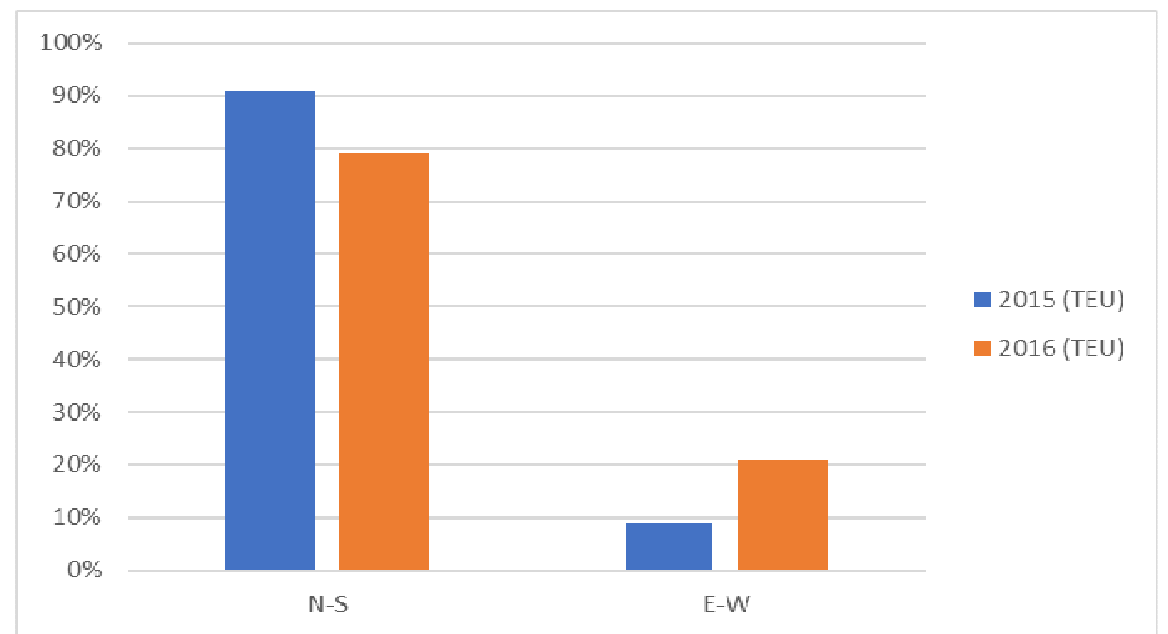

(Source: Own work)

Diagram 2: Trend of containers handled along E-W (east-west) line

As far as handling of other cargoes (bulk, metallurgical, palletized and noncontainerized) is concerned, percentages of cargoes handled (loaded and unloaded) on broad-gauge $(1520 \mathrm{~mm})$ and standard-gauge $(1435 \mathrm{~mm})$ cars and road vehicles are provided in Diagram 3.

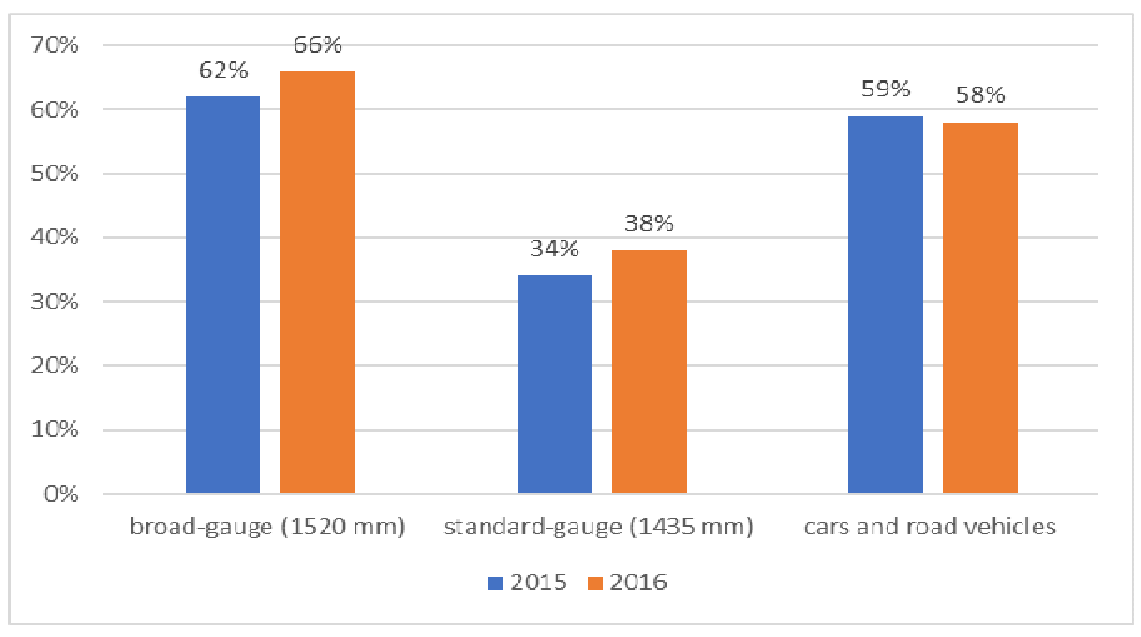

Diagram 3: Handling of other cargoes (bulk, metallurgical, palletized and non-

(Source: Own work) containerized)

Huge contribution in cargoes transshipped in "Euroterminal Sławków" is attributed to road transport which performs delivery and pickup functions (main areas covered by this type of transport are: southern Poland, Czech 
Republic, Austria and Germany) in relation to cargo shipped by and received from rail transport.

Due to constantly increasing volume of container transshipment [from 2008 to 2010], the volume increased from 4798 TEU (monthly average in 2008) to 14,496 TEU (monthly average for 10 months of 2010), whereas in October, 20,496 TEU was transshipped, "Euroterminal Sławków". Logistics Center is planning to realize further investments pertaining to IT system improving process management and enabling coordination with market partners. This will help to facilitate logistics service, shorten operation time, improve transport safety and standardize procedures directly affecting the increase of service quality. As a result of increasing transshipment volume in Euroterminal, storage and transshipment infrastructure for handling containerized cargoes are going to be extended. Upon the completion of investment works, Euroterminal's transshipment capacity should increase to approx. 400,000-500,000 TEU per year (Ibidem).

Attempting to evaluate the operation of "Euroterminal Sławków" Logistics Center in view of its undertakings and tasks, it should be stated that the center is prepared for comprehensive logistics handling of goods on both national and international level using rail/road transport and warehouse infrastructure. The Company is currently aiming at increasing the number of containerized cargoes handled by Euroterminal along W-E line. The terminal displays an enormous potential to develop intermodal transport on global level. One of its operations may be related to a new intermodal connection referred to as „Słowiański Express” (Slavonic Express), opened during the third quarter of 2011 in cooperation with e.g. PKP LHS Sp. z o.o., Hupac Intermodal, Fesco and Russkaya Troyka, connecting Sławków and Bryansk. Cargoes delivered from Western Europe by rail are transshipped onto flat container broad-gauge cars. This is a regular connection (trains depart from Euroterminal in Sławków every Wednesday). A block train is to supply goods to Russia.

Since Euroterminal in Sławków is also well located for maritime transport (with increasing importance of Baltic ports in Gdańsk and Gdynia), series of containerized cargoes sent along north-south line are crucial for the Company's business. Cooperation in the form of intermodal connections with Gdynia is planned to be extended in the foreseeable future. As part of cooperation with Mearsk Polska, intermodal transport is going to be provided in Sławków or in Katowice area for southern Poland with potential further eastward expansion using broad-gauge railway. Moreover, discussions concerning intermodal north-south connections from seaports via Sławków towards Austria and Slovenia are held.

\section{Conclusions}

In modern times characterized with dynamic globalization, intermodal services provided by logistics centers in respect of transport are fundamental and condition a company's market presence, its efficient operation and proper satisfaction of demand and market expectations. They include various actions - in particular intermodal transport services, such as road, rail, maritime/inland, air or pipeline transport. One of advantages of such centers is their ability to utilize the most effective and economic means of transport, contributing to streamline logistics operations taken internally and externally within the entire supply chain process. A model example of such center providing the aforementioned service is "Euroterminal" International Logistics Center in Sławków.

\section{References}

1. Agami N., Saleh M., Mohamed Rasmy M. (2012), "Supply Chain Performance Measurement Approaches: Review and Classification", Journal of Organizational Management Studies, Article ID 872753, DOI: $10.5171 / 2012.872753$ 
2. Bömer G. C., Tadeu R. L. (2014), "The South America East Coast Reefer Cargo: A Diagnosis of a Competitive Market ", IBIMA Business Review, Vol. 2014 (2014), Article ID 309732, DOI: $10.5171 / 2014.309732$

3. Euroterminal Sławków Sp. $\mathrm{z} \quad$ o.o., (Online), (Retrieved: May, 15, 2017). www.czh.pl/spolka/euroterminal-slawkow/.

4. Kalinzi Ch. (2016), "Outsourcing (Logistics) Services and Supply Chain Efficiency - A Critical Review of Outsourcing Function in Mukwano Group of Companies" Journal of Outsourcing \& Organizational Information Management, Vol. 2016 (2016), Article ID 937323, DOI:10.5171/2016.937323

Coyle J. J., Bardi E. J., Langley Jr. C. J (2010), Zarządzanie logistyczne, PWE, Warszawa.

5. Fajczak-Kowalska A. (2013), Transport kolejowy w procesach logistycznych polskiej gospodarki, Uniwersytet Łódzki, Łódź.

6. Kisperska-Moroń D, (ed.) (2009), Logistyka, red. D. Kisperska-Moroń, S. Krzyżaniak, Biblioteka Logi styka, Poznań.

7. Kowalska-Napora E. (2015), Infrastruktura logistyczna, Ekonomicus, Warszawa.

8. Liberadzki B. and Mindur L. (2007), Uwarunkowania rozwoju systemu transportowego Polski, Instytut Technologii Eksploatacji, Warszawa - Radom.

9. Majchrzak-Lepczyk J. and Gołembska Z. and E. (2015), Eurologistyka aktualne trendy rozwoju najnowsze wyniki badań sprawdzone metody zarządzania, PWE, Warszawa.

10. Rydzykowski W. (2011), Usługi logistyczne. Teoria i praktyka, Instytut Logistyki i Magazynowania, Warszawa.
11. Skowronek Cz. and Sariusz - Wolski Z. (2012), Logistyka w przedsiębiorstwie, PWE, Warszawa.

12. Witkowski J. (2010), Zarządzanie łańcuchem dostaw, PWE, Warszawa.

13. Zamkowska S. and Zagożdżon B. (2015), Systemy logistyczne w obsłudze przedsiębiorstw, Uniwersytet Technologiczno-Humanistyczny, Radom.

\section{Conference Paper}

Grenda B., Ślachcińska E., Majdan P., Terrorist Threats for the Critical Infrastructure of the State, 2017 4th International Conference on Management Science and Management Innovation, June 23-25, 2017 Suzhou, China, Published by Atlantis Press, ISSN: part of the series AEBMR, ISBN: 978-94-6252-369-2, ISSN 2352-5428, volume 31, pp. 165-169, doi:10.2991/msmi-17.2017.37.

Ying Wei (2016), Research on Intermodal External Costs of International Container, 2nd International Conference on Education Technology, Management and Humanities Science, doi:10.2991/etmhs-16.2016.60 